\title{
Long-term clinical follow-up of patients with choroidal osteoma
}

\section{Długoterminowa obserwacja pacjentów z kostniakiem naczyniówki}

\author{
Anna Markiewicz',2, Justyna Jędrychowska-Jamborska', Bożena Romanowska-Dixon ${ }^{1,2}$ \\ Department of Ophthalmology and Ocular Oncology, University Hospital, Kraków, Poland \\ Head: Professor Bożena Romanowska-Dixon, MD, PhD \\ 2 Department of Ophthalmology and Ocular Oncology of the Jagiellonian University Medical College, Kraków, Poland \\ Head: Professor Bożena Romanowska-Dixon, MD, PhD
}

\begin{abstract}
Ahstract: $\quad$ Aim: To analyse symptoms, disease course, comorbidities, complications and treatment in eleven-year follow-up of patients with choroidal osteoma.

Material and methods: Twelve eyes of 3 men and 8 women were analysed.

Results: Choroidal neovascularization was observed in 5 eyes (41.6\%), intraretinal fluid without features of choroidal neovascularization was observed in one case; there was also a single case of epiretinal membrane. Retinal pigment epithelium and Bruch membrane dystrophy alongside accumulation of subretinal fluid and intraretinal haemorrhage were observed in all cases of choroidal neovascularization, there was also one case of subretinal haemorrhage. Two patients with choroidal neovascularization were treated with anti-VEGF injections. The photodynamic therapy was used in one case. The majority (86\%) of cases without choroidal neovascularization had visual acuity of $20 / 25$ or better. In patients with choroidal neovascularization, the majority (80\%) had visual acuity of 20/40 or lower. Anti-VEGF therapy (ranibizumab) improved visual acuity by 3 rows and stabilised it for a period of 20 months. Both discussed treatment methods accelerated decalcification, retinal pigment epithelial atrophy and subretinal fibrosis, which slowed down tumour growth.

Conclusions: Anti-VEGF injections are the best option to inhibit tumour progression and should be used in cases with choroidal neovascularization.

Key words: $\quad$ choroidal osteoma, tumour, anti-VEGF therapy.

Abstrakt: $\quad$ Cel: Analiza objawów, przebiegu choroby, schorzeń wspótistniejących, powikłań i stosowanego leczenia w obserwacji długoterminowej (11 lat) pacjentów z kostniakiem naczyniówki.

Materiał i metoda: analizą objęto 12 oczu 3 mężczyzn i 8 kobiet.

Wynik: W 5 oczach $(41,6 \%)$ stwierdzono neowaskularyzację podsiatkówkową. W jednym przypadku stwierdzono obecność płynu śródsiatkówkowego, któremu nie towarzyszyła neowaskularyzacja posiatkówkowa. W jednym przypadku rozpoznano błonę nasiatkówkową. Dystrofię nabłonka barwnikowego i błony Brucha, oraz płyn podsiatkówkowy i krwotoki śródsiatkówkowe obserwowano we wszystkich przypadkach ze wspótistniejącą neowaskularyzacją podsiatkówkową, w jednym z przypadków stwierdzono krwotok podsiatkówkowy. Dwoje pacjentów z neowaskularyzacją podsiatkówkową leczono doszklistkowymi iniekcjami anty-VEGF. Terapię fotodynamiczną zastosowano w jednym przypadku. Najlepsza skorygowana ostrość wzroku u większości (86\%) pacjentów bez neowaskularyzacji podsiatkówkowej była wyższa lub równa 20/25, natomiast większość pacjentów (80\%) z neowaskularyzacją podsiatkówkową miało ostrość wzroku niższą lub równą 20/40. Leczenie anty-VEGF (ranibizumab) poprawiało ostrość wzroku o 3 rzędy i stabilizowało ją na okres 20 miesięcy. Obie omówione metody leczenia przyspieszały procesy dekalcyfikacji, zaniku nabłonka barwnikowego siatkówki i włóknienia podsiatkówkowego, co spowalniało wzrost guza.

Wnioski: Doszklistkowe iniekcje anty-VEGF stanowią najlepszą opcję hamowania progresji guza i powinny być stosowane w przypadkach kostniaka naczyniówki wspótistniejącego z neowaskularyzacją podsiatkówkową.

Slowa kluczowe: kostniak naczyniówki, guz naczyniówki, terapia anty-VEGF.

The authors declare no conflict of interest/ Autorzy zgłaszają brak konfliktu interesów w związku z publikowaną pracą
\end{abstract}

\section{Introduction}

Choroidal osteoma was first described by van Dyk in 1975 (1). The tumour is located in the peripapillary area and papillary-macular band, hardly ever only in the paramacular area $(2,3)$. The colour of the lesions varies from yellow-white to orange-red with or without covering pigment. The colour variation is associated with tumour metabolism depending on depigmentation of the retinal pigment epithelium (1). Intensive orange-red areas indicate the presence of calcifications, the colour is the result of intact, normal retinal pigment epithelium covering the tumour; while white-yellow areas indicate decalcified regions (4). Histologically, the tumour is a dense cancellous bone with narrow spaces intersected by dilated thin-walled blood vessels referred to as "spider vessels" or "feeder vessels". Those vessels seem to connect choriocapillaries with larger choroidal vessels $(1,5,6)$. 
The prevalence of choroidal osteoma remains unknown. It is considered an extremely rare tumour as bigger clinical centres only report several cases. A study of choroidal osteoma in patients of the Wills Eye Hospital demonstrated 74 cases in 61 patients (13 cases of bilateral choroidal osteoma) over the analysed period of 26 years (7). The precise aetiology is unknown, as well. Diagnosis is based on characteristic clinical and ultrasound features - the lesion appears hyperechoic. Additional diagnosis investigations include optical coherence tomography (OCT), fluorescein angiography (FA), indocyanine green angiography (ICGA) and computed tomography (CT).

The tumour is metabolically active and grows slowly with progressive decalcification, which causes complications and visual loss. The study by Shields in 61 patients monitored for 10 years demonstrated tumour growth occurring in $51 \%$ of cases, decalcification - in $50 \%$ of cases, and visual acuity (VA) of $20 / 200$ or less in $56 \%$ of cases (7). Another long-term (10-year follow-up) study by Aylwerd et al. on 36 patients showed tumour growth in $41 \%$ of cases and VA of $20 / 200$ or less in $58 \%$ of cases (8). The complications of choroidal osteoma include subretinal fluid accumulation, subretinal neovascularization, as well as inter- and/or subretinal haemorrhage. Subretinal fluid can accumulate as a result of exfoliation and atrophy of the retinal pigment epithelium (RPE) or leakage from abnormal blood vessels of the subretinal membrane. RPE has many physiological functions, one of which includes transportation of fluid produced by metabolically active retina to choriocapillaries (9). Tumour bone metabolism leads to decalcification causing damage and atrophy of the overlying retinal pigment epithelium (8). The second mechanism is the development of choroidal neovascularization (CNV). CNV is the most common cause of vision loss in patients with choroid osteoma; it occurs in $31 \%$ to $47 \%$ of cases over a 10 -year follow-up $(4,7)$.

Currently, long-term watchful waiting is recommended in patients with choroidal osteoma. If tumour growth poses a risk to the macula, laser coagulation and PDT were attempted in numerous studies to inhibit its further progression.

\section{Material and methods}

Twelve eyes of eleven patients ( 3 men and 8 women) with choroidal osteoma were enrolled. All patients underwent a comprehensive eye examination and ocular ultrasound. Additionally, fluorescein angiography and optical coherent tomography were performed in seven cases. OCT examinations were performed using TOPCON's 3D OCT 2000 and Optovue tomographs, as Grid, Line, EMM5, 3D Reference scans. Swept source OCT (SS-OCT Atlantis DRI OCT-1, Topcon, Japan) was used in 3 cases to acquire 3D Macula $6.0 \times 6.0 \mathrm{~mm}$, Radial Dia $6.0 \mathrm{~mm}$ and 5 LineCross $9.0 \mathrm{~mm}$ tomograms. The following were included in the analysis: sex, age, first reported symptom, best corrected visual acuity, ophthalmic, family and general history, as well as complications and treatment.

One patient with subretinal neovascular membranes secondary to choroid osteoma was treated with a total of 3 intravitreal anti-VEGF injections (bevacizumab $1.25 \mathrm{mg}$ in $0.05 \mathrm{ml}$ ), another patient with subretinal neovascular membranes secondary to choroid osteoma was treated with a total of 6 intravitreal anti-VEGF injections (ranibizumab $0.5 \mathrm{mg}$ in $0.05 \mathrm{ml}$ ). Photody- namic therapy (PDT) (Verteporfin $6 \mathrm{mg} / \mathrm{m}^{2}$; Visudyne, Bausch \& Lomb, the laser energy $50 \mathrm{~J} / \mathrm{cm}^{2}$, irradiance of $600 \mathrm{~mW} / \mathrm{cm}^{2}$ ) was used in one case.

\section{Results}

Observation of patients with choroidal osteoma continued for 11 years between 2005 and 2016. 3 men and 8 women were enrolled. The mean age on diagnosis was 30.5 years ( 29.6 years in women and 33 years in men). The right eye was involved in 4 patients and left eye in 6 patients. There was one case of bilateral choroidal osteoma. The most common first reported symptom was vision deterioration without metamorphopsia in 6 patients, vision deterioration with metamorphopsia in 3 patients, stand-alone metamorphopsia in 1 patient and in light flashes in 1 patient. The VA upon diagnosis was $20 / 20$ in 5 cases and 20/25 in 3 cases. There were also single cases of 20/50, 20/100, counting fingers at 3 meters and counting fingers at 1 metre vision. Overall, $66 \%$ of studied eyes had VA equal to $20 / 25$ or better and $33 \%$ of studied eyes had VA below 20/25. Ocular history was unremarkable in 9 patients (81.8\%). General medical history was unremarkable in 8 patients (72.7\%). Five patients (41.6\%) presented with CNV, one with intraretinal fluid (IRF) without features of CNV, and another one with epiretinal membrane (ERM). All patients with CNV, were found to have RPE and Bruch membrane dystrophy, subretinal fluid (SRF) and intraretinal haemorrhage (IRH). Additionally, there was one case of subretinal haemorrhage (SRH).

At the end of the follow-up, the visual acuity was 20/20 in 5 eyes and 20/25 in 2 eyes. There were also single cases of $20 / 40,20 / 100$, counting fingers in front of the eye and counting fingers at 1 metre vision, plus one patient was lost to follow-up. $86 \%$ of patients without CNV had VA of $20 / 25$ or better. In one female without CNV, the VA was counting fingers in front of the eye, which could have been attributable to amblyopia secondary to strabismus as well as subretinal fluid secondary to RPE atrophy. $80 \%$ of patients with CNV had VA of 20/40 or lower.

Both PDT and anti-VEGF treatments improved CNV and subretinal fluid. In a patient treated with PDT, VA did not improve yet it remained stable over the 18 month-long follow up. Anti-VEGF treatment improved VA by 3 rows and stabilised it for 20 months. Both treatments accelerated decalcification with RPE atrophy and subretinal fibrosis slowing down tumour growth (Tab. I).

\section{Discussion}

Choroidal osteoma is a tumour composed of cancellous bone and contains metabolically active bone cells responsible for continuous remodelling of tumour tissue (Fig. 1). Decalcification is a clinically important prognostic factor (10). Decalcification and tumour decomposition, first described by Trimbl in 1988, are present in about $50 \%$ of cases and are characterized by RPE thinning and choriocapillaris atrophy. Tumour decalcification in the macular region is associated with low visual acuity $(4,7,11,12)$. Its onset can be spontaneous or induced by laser photocoagulation or PDT, which stimulate osteoclast activity in the lesion $(11,13,14,15)$. Navajas et al. identified 2 different reflective patterns in decalcified regions, the first consisting of areas of relati- 


\begin{tabular}{|c|c|c|c|c|c|c|c|c|c|c|c|c|}
\hline & $\begin{array}{l}\text { Sex/ } \\
\text { Płeć }\end{array}$ & $\begin{array}{l}\text { Age/ } \\
\text { Wiek }\end{array}$ & $\begin{array}{l}\text { Involved } \\
\text { eye/ } \\
\text { Zajęte } \\
\text { oko }\end{array}$ & $\begin{array}{c}\text { First } \\
\text { symptom/ } \\
\text { Pierwsze } \\
\text { objawy }\end{array}$ & $\begin{array}{c}\text { Ocular } \\
\text { history/ } \\
\text { Wywiad } \\
\text { okulistyczny }\end{array}$ & $\begin{array}{c}\text { General } \\
\text { history/ } \\
\text { Wywiad } \\
\text { ogólny }\end{array}$ & $\begin{array}{l}\text { Family } \\
\text { history/ } \\
\text { Wywiad } \\
\text { rodzinny }\end{array}$ & CNV & $\begin{array}{l}\text { Comorbidi- } \\
\text { tie/ Zmiany } \\
\text { współ- } \\
\text { istniejące }\end{array}$ & $\begin{array}{l}\text { VA on } \\
\text { diagnosis/ } \\
\text { Ostrość } \\
\text { wzroku } \\
\text { podcas } \\
\text { rozpoznania }\end{array}$ & $\begin{array}{c}\text { Final VA/ } \\
\text { Ostateczna } \\
\text { ostrość } \\
\text { wzroku }\end{array}$ & $\begin{array}{c}\text { Treatment/ } \\
\text { Zasto- } \\
\text { sowane } \\
\text { leczenie }\end{array}$ \\
\hline 1 & M & 63 & L & $\begin{array}{l}\text { decreased } \\
\text { vision }\end{array}$ & negative & negative & negative & - & - & $20 / 20$ & $20 / 20$ & 0 \\
\hline 2 & $\mathrm{~F}$ & 17 & $\mathrm{R}$ & $\begin{array}{l}\text { decreased } \\
\text { vision }\end{array}$ & $\begin{array}{l}\text { strabismus } \\
\text { (RE) }\end{array}$ & negative & negative & - & IRF & $\begin{array}{l}\text { count } \\
\text { fingers at } \\
1 \mathrm{~m}\end{array}$ & $\begin{array}{l}\text { count } \\
\text { fingers } \\
\text { at } 1 \mathrm{~m}\end{array}$ & 0 \\
\hline 3 & $\mathrm{~F}$ & 24 & L & $\begin{array}{l}\text { decreased } \\
\text { vision }\end{array}$ & negative & negative & negative & - & ERM & $20 / 20$ & $20 / 20$ & 0 \\
\hline 4 & $M$ & 15 & $\mathrm{R}$ & $\begin{array}{l}\text { metamor- } \\
\text { phopsia }\end{array}$ & myopia & negative & negative & - & - & $20 / 25$ & $20 / 25$ & 0 \\
\hline 5 & $\mathrm{~F}$ & 20 & $\mathrm{~L}$ & $\begin{array}{l}\text { decreased } \\
\text { vision }\end{array}$ & negative & negative & negative & + & IRH & $\begin{array}{l}\text { count } \\
\text { fingers at } \\
3 \mathrm{~m}\end{array}$ & unknown & anti-VEGF \\
\hline 6 & $\mathrm{~F}$ & 29 & L & $\begin{array}{l}\text { decreased } \\
\text { vision }\end{array}$ & negative & negative & negative & + & $\begin{array}{l}\text { SRF } \\
\text { SRH }\end{array}$ & $20 / 50$ & $20 / 100$ & PDT \\
\hline 7 & $\mathrm{~F}$ & 50 & $\mathrm{R}$ & $\begin{array}{l}\text { decreased } \\
\text { vision } \\
\text { metamor- } \\
\text { phopsia }\end{array}$ & negative & $\begin{array}{c}\text { hyperlipidemia } \\
\text { hypertension } \\
\text { Lyme disease }\end{array}$ & $\begin{array}{c}\text { Aunt } \\
\text { - brest } \\
\text { cancer }\end{array}$ & - & - & $20 / 25$ & $20 / 25$ & 0 \\
\hline 8 & $\mathrm{~F}$ & 57 & L & $\begin{array}{l}\text { decreased } \\
\text { vision }\end{array}$ & negative & negative & negative & - & - & $20 / 20$ & $20 / 20$ & 0 \\
\hline 9 & $M$ & 21 & $\mathrm{R}$ & flashes & negative & negative & negative & + & SRF & $20 / 20$ & $20 / 20$ & 0 \\
\hline 10 & $\mathrm{~F}$ & 20 & $\mathrm{R}, \mathrm{L}$ & $\begin{array}{l}\text { decreased } \\
\text { vision } \\
\text { metamor- } \\
\text { phopsia }\end{array}$ & negative & negative & negative & $\begin{array}{l}+ \text { in RE } \\
- \text { in LE }\end{array}$ & $\begin{array}{l}\text { IRH } \\
\text { SRF } \\
\text { SRH }\end{array}$ & $\begin{array}{l}20 / 25 \\
20 / 20\end{array}$ & $\begin{array}{c}\text { count } \\
\text { fingers } \\
\text { in front } \\
\text { of the eye } \\
20 / 20\end{array}$ & 0 \\
\hline 11 & $\mathrm{~F}$ & 20 & $\mathrm{~L}$ & $\begin{array}{l}\text { decreased } \\
\text { vision } \\
\text { metamor- } \\
\text { phopsia }\end{array}$ & negative & CMV & negative & + & SRF & $20 / 100$ & $20 / 40$ & anti- VEGF \\
\hline
\end{tabular}

R - right, L - left, (+) - present, (-) - absent, RE - right eye, LE - left eye, M - male, F- female, IRF - Intraretinal fluid, SRF - subretinal fluid, CNV - choroidal neovascularization, ERM - epiretinal membrane, IRH - intraretinal hemorrhage, PDT - photodynamic therapy, Anti-VEGF therapy - anti-vascular endothelial growth factor therapy, BCVA - best corrected visual acuity, 0 - observation, CMV - cytomegalovirus

Tab. I. Clinical characteristics of patients with choroidal osteoma: BCVA, complications, comorbidities, and treatments.

Tab. I. Charakterystyka kliniczna pacjentów z kostniakiem naczyniówki: BCVA, powikłania, schorzenia wspótistniejące i zastosowane leczenie.

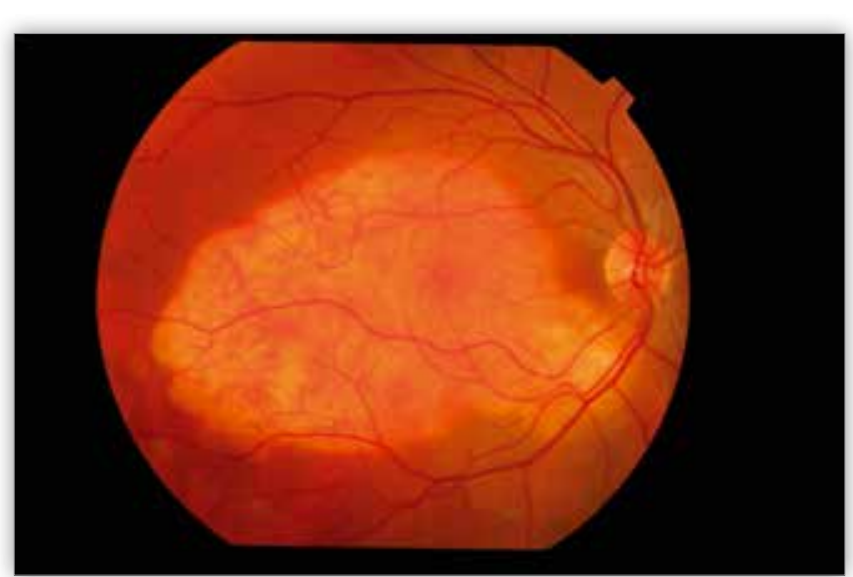

Fig. 1. Typical choroidal osteoma in fundus examination.

Ryc. 1. Typowy obraz kostniaka naczyniówki w badaniu dna oka. ve hyperreflectivity with a lamellar appearance and the second being characterized by heterogeneously, hyperreflective, mound-like irregular areas. They suggested that the areas of lamellar reflective pattern would correspond to posterior scleral tissue where little or no tumour tissue is left, whereas hyperreflective mound-like irregular areas associated with some posterior shadowing may correspond to tumour regions in which spongy organization was lost secondary to partial decalcification. (16). In our patients, we observed changes in tumour colour in funduscopy, alongside RPE and Bruch membrane atrophy in OCT, as well as characteristic changes in $\mathrm{AF}$, which collectively indicate tumour decalcification (Fig. 2a, 2b).

Choroidal osteoma is asymptomatic in 8 to $30 \%$ of the cases $(7,8)$. Most commonly reported symptoms include blurred vision and metamorphopsia, just as it was the case in our patients. The tumour grows at a mean rate of $0.37 \mathrm{~mm}$ per year (7). 

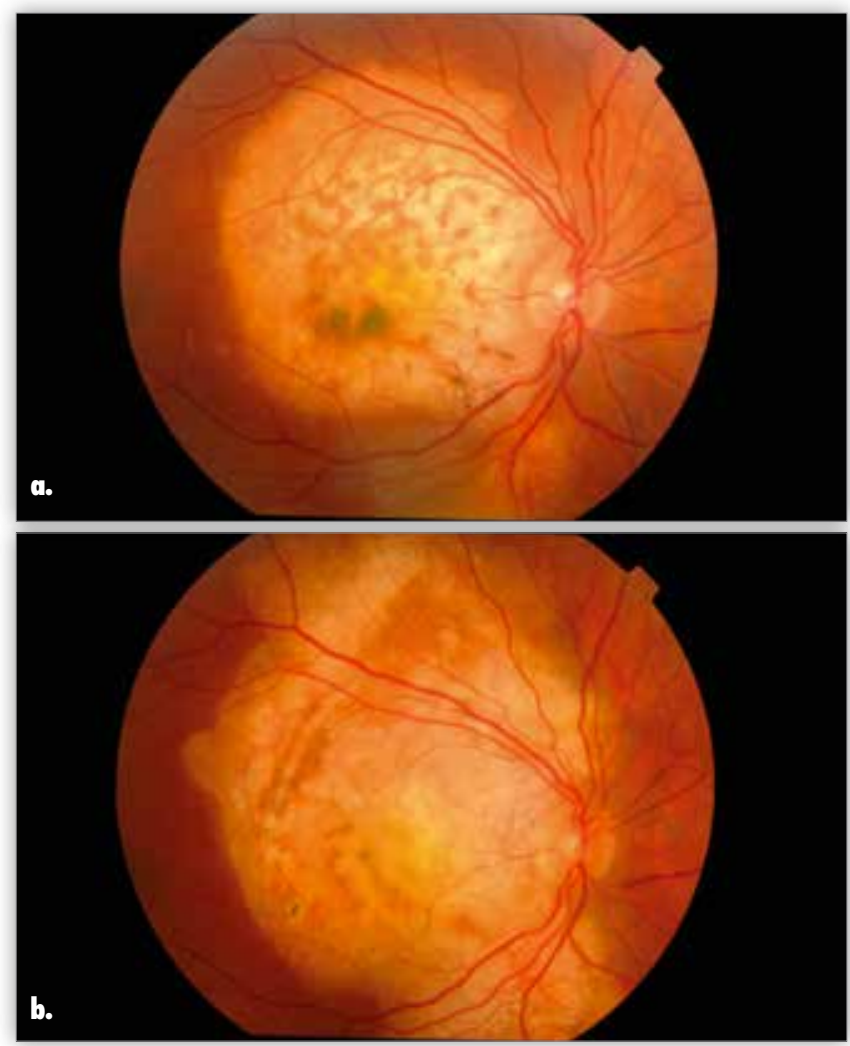

Fig. 2. Colour change within the tumour indicating its decalcification. Ryc. 2. Zmiana zabarwienia guza wskazująca na jego dekalcyfikację.

Current theories on the origin of choroidal osteoma include congenital causes (17), choristoma (5), inflammation (18, 19), and hormonal abnormalities $(3,20)$. Several cases of familial occurrence were reported $(3,17,21,22)$. There was no familial occurrence in our patients, though. Sporadic reports tie choroidal osteoma with Stargardt macular dystrophy (23), polypoid choroidal maculopathy (24), pregnancy $(20,25)$, orbital pseudotumour (18), intraocular inflammation (19) and histiocytosis X (26). No connection was found between choroidal osteoma and biochemical abnormalities in blood, such as calcium, phosphorus, alkaline phosphatase or urea nitrogen levels $(3,27)$. In line with this finding, the calcium-phosphate balance was within normal limits in our patients. One female in our sample was treated for hyperlipidaemia. Another female was treated for hypertension and had a history of Lyme disease. A third female had a history of CMV infection.

A standard diagnostic assessment of choroidal osteoma includes indirect imaging using Volk lens and ocular ultrasound (Fig. 3). OCT can aid both the diagnosis and assessing potential complications. Specifically, it enables evaluating the presence of subretinal fluid, retinal thickness, morphology and the structure of individual retinal layers. The greatest attention should be paid to the presence of neovascular membranes, continuity of ELM layers, photoreceptors and RPE. OCT can indicate areas of variable reflectance, depending on the degree of tumour calcification. Decalcified areas are more hyperreflective (28). Recently introduced swept-source OCT (SS-OCT) enables a more accurate visualisation picture of the choroid and of pathology, including tumour type differentiation (29, 30) (Fig. 4).

AF is helpful in detecting RPE atrophy, CNV and the characteristic "spider vessels". Autofluorescence increases in meta-

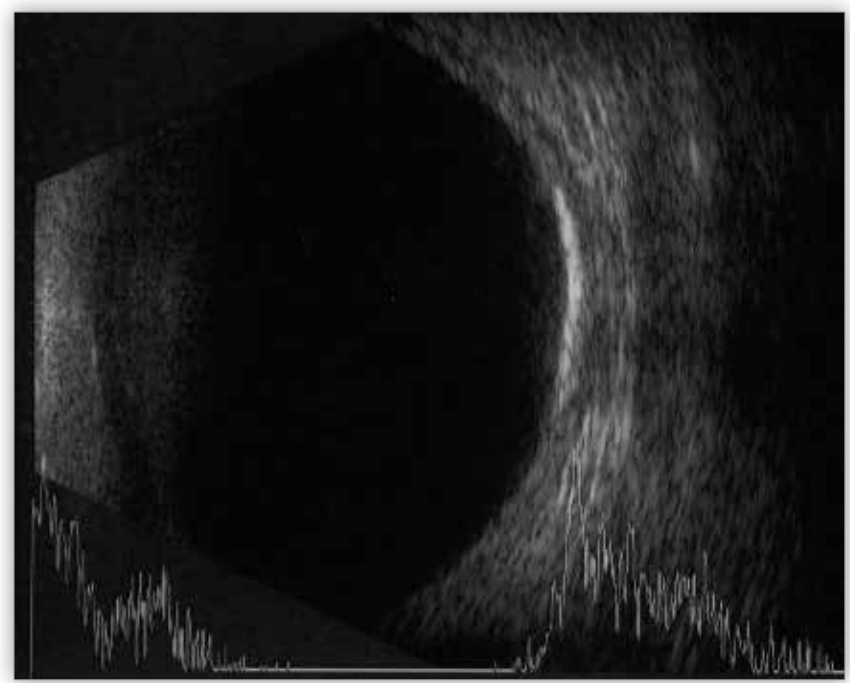

Fig. 3. Ultrasound image of choroidal osteoma.

Ryc. 3. Obraz kostniaka naczyniówki w badaniu ultrasonograficznym.

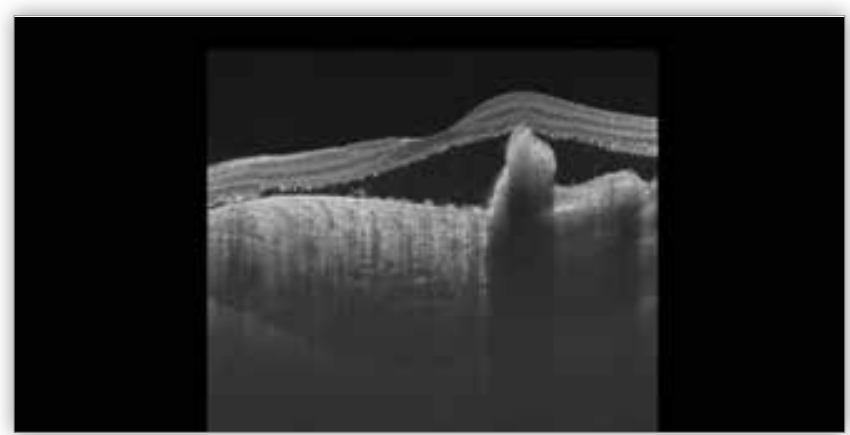

Fig. 4. The choroidal osteoma disrupting Bruch membrane and causing retinal elevation seen in an OCT.

Ryc. 4. Kostniak naczyniówki w badaniu OCT - widoczne zaburzenie przebiegu błony Brucha i uniesienie siatkówki.

bolically active tissues and is, therefore, absent in RPE atrophy and dysfunction. Fluorescence of calcified areas is well preserved and reduced in decalcified regions. It is very well visible in FA in our patients (Fig. 2). In indocyanine green angiography (ICGA), hypofluorescence in early-stage ICGA and retention of dye in late-phase ICGA were observed. Both calcified and decalcified appeared hypofluorescent. ICGA enables imaging small blood vessels on tumour surface, especially in early-phase stu$\mathrm{dy}$, whereas vascular networks which may leak are often not detected using FA (31).

Many authors draw attention to the problem of subretinal fluid accumulation in eyes with choroidal osteoma. Shields postulated that disruptions in RPE promote the growth of new choroidal vessels (27). Alternatively, Foster's theory assumes that CNV is the extension of the osteoma vessels (32). This hypothesis is supported by osteoclast detection in surgically removed neovascular membranes (33). In fact, CNV was only found in $23 \%$ of eyes with subretinal fluid. High metabolic rate in choroidal osteoma, can restrict blood flow in adjacent tissues, particularly in RPE overlying tissue, which may increase VEGF expression. Presumably, then, CNV develops secondarily to the disruption of the epithelium - Bruch complex (33) (Fig. 5).

VA reduction can be caused by progressive retinal atrophy, subretinal fluid accumulation, and subretinal haemorrhage with or without the presence of CNV (4). The subretinal 


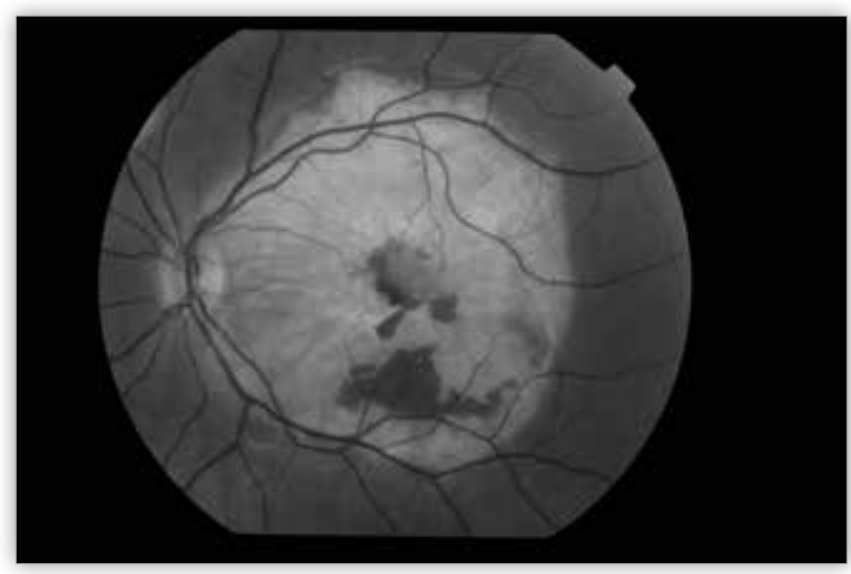

Fig. 5. Subretinal haemorrhage within the choroidal osteoma in autofluorescence imaging.

Ryc. 5. Krwawienie podsiatkówkowe w obrębie kostniaka naczyniówki w badaniu autofluorescencji dna oka.

haemorrhage can be caused by intracranial pressure elevated as a result of Valsalva manoeuvre (34). This very mechanism was observed in one female in our sample. In their report, Koylu et al. present a case of spontaneously resolving subretinal haemorrhage secondary to choroidal osteoma unrelated to CNV. They believe that bleeding may have been caused by spontaneous rupture of choroidal vessels which were distorted by the lesion and suggest that clinicians should rule out the presence of CNV in secondary subretinal haemorrhage of choroidal osteoma and prevent unnecessary treatment attempts in the first step as spontaneous recovery is the easiest and safest way (35). Another study provides CNV prevalence rates as $31 \%$ in 5 years, $31-47 \%$ in 10 years, and $56 \%$ in 20 years (36). In our sample, CNV was present in $41.6 \%$ of eyes within 10 years.

As far as treatment is concerned, some authors state that laser photocoagulation in the treatment of choroidal osteoma has limited efficacy due to the lack of pigment in the tumour and to the atrophy of retinal pigment epithelium (37). This method was not used in any of our patients. PDT, administered at the standard dose of $6 \mathrm{mg} / \mathrm{m}^{2}$, offers stable visual acuity, reduced metamorphopsia and CNV improvement. In one female from our sample, the best corrected visual acuity (BCVA) remained stable for 18 months after PDT and was accompanied by CNV and subretinal fluid resolution. Shields et al. also described a case of a subfoveal CNV accompanying choroidal osteoma, successfully treated using PDT (13). The results of another study show that PDT was effective in only $25 \%$ of classic subfoveal CNV complicating choroidal osteoma (8). PDT in choroidal osteoma increases the risk of tumour decalcification. Our study revealed accelerated tumour decalcification with subretinal fibrosis after PDT, which whilst limiting further tumour growth, additionally accelerated RPE atrophy in the macula. Shields et al. state that PDT may be a therapeutic option for CNV and for induction of decalcification for perimacular tumours to prevent their growth towards the macula (13). Our observations seem to confirm it. In some centres, PDT is combined with intravitreal injections of anti-VEGF to treat CNV complicating choroid osteoma. The first treatment of this kind, combining PDT with ranibizumab was described by Morris et al. and resulted in visual acuity improvement from $20 / 80$ to $20 / 20$ (38).
The results of recent studies suggest that intravitreal anti-VEGF injections offer a good option to improve visual acuity $(30,33)$. In Poland, approved anti-VEGF products include bevacizumab, ranibizumab and aflibercept, with bevacizumab used off-label. All anti-VEGF agents are angiogenesis inhibitors, which block or slow down growth of pathological blood vessels in the subretinal space and/or under the RPE. Using ranibizumab instead of bevacizumab reduces systemic exposure as it has a much shorter half-life in serum. Good response to anti-VEGF therapy can also be explained by young age of patients with choroidal osteoma. One female in our sample received 6 intravitreal anti-VEGF injections of ranibizumab, achieving partial resolution of CNV and subretinal fluid, as well as BCVA improvement from 0.2 to 0.5 with its subsequent stabilisation for 20 months.

\section{Summary}

The literature review and our long-term observations indicate that choroidal osteoma is an extremely rare tumour affecting mostly young women and located within the posterior pole. Diagnosis should include ultrasound examination, which shows hyperechoic tumour. Over time, the tumour gradually decalcifies, which is clearly visible in fluorescein angiography and OCT. Possible complications can include subretinal membrane. Choroidal osteomas can remain asymptomatic. Intravitreal injections of anti-VEGF agents or, optionally, combined treatment with PDT, should be considered as adjunctive treatment of choroidal osteoma.

\section{References:}

1. Gass JD, Guerry RK, Jack RL, Harris G: Choroidal osteoma. Archives of Ophthalmology. 1978; vol. 96, no. 3: pp. 428-435.

2. Browning DJ: Choroidal osteoma: observations from a community setting. Ophthalmology. 2003; vol. 110, no. 7: pp. 1327$-1334$.

3. Gass JDM: New observations concerning choroidal osteomas. International Ophthalmology. 1979; vol. 1, no. 2: pp. 71-84.

4. Shields CL, Perez B, Materin MA, Mehta S, Shields JA: Optical coherence tomography of choroidal osteoma in 22 cases. Evidence for photoreceptor atrophy over the decalcified portion of the tumour. Ophthalmology. 2007; vol. 114, no. 12: pp. 53-58.

5. Williams AT, Font RL, van Dyk HJ, Riekhof FT: Osseous choristoma of the choroid simulating a choroidal melanoma. Association with a positive $32 P$ test. Arch Ophthalmol. 1978; 96: 1874-1877.

6. Chen J, Lee L, Gass JD: Choroidal osteoma: Evidence of progression and decalcification over 20 years. Clin Exp Optom. 2006; 89: 90-94.

7. Shields CL, Sun H, Demirci H, Shields JA: Factors predictive of tumour growth, tumour decalcification, choroidal neovascularization, and visual outcome in 74 eyes with choroidal osteoma. Archives of Ophthalmology. 2005; vol. 123, no. 12: pp. 1658$-1666$.

8. Aylward GW, Chang TS, Pautler SE, Gass MD: A long-term follow-up of choroidal osteoma. Archives of Ophthalmology. 1998; vol. 116, no. 10: pp. 1337-1341.

9. Strauss 0: The retinal pigment epithelium in visual function. Physiological Reviews. 2005; vol. 85, no. 3: pp. 845-881. 
10. Yoshikawa T, Takahashi K. Decalcified choroidal osteoma found in the retina. Clin Ophthalmol. 2012;6:1823-5.

11. Trimble SN, Schatz H: Decalcification of a choroidal osteoma. Br J Ophthalmol. 1991; 75: 61-63.

12. Trimble SN, Schatz H, Schneider GB: Spontaneous decalcification of a choroidal osteoma. Ophthalmology. 1988; 95: 631-634.

13. Shields CL, Materin MA, Mehta S, Foxman BT, Shields JA: Regression of extrafoveal choroidal osteoma following photodynamic therapy. Archives of Ophthalmology. 2008; vol. 126, no. 1: pp. 135-137.

14. Gurelik G, Lonneville Y, Safak N, Ozdek SC, Hasanreisoglu B: A case of choroidal osteoma with subsequent laser induced decalcification. Int Ophthalmol. 2001; 24: 41-43.

15. Rose SJ, Burke JF, Brockhurst RJ: Argon laser photoablation of a choroidal osteoma. Retina. 1991; 11: 224-228.

16. Navajas EV, Costa RA, Calucci D, Hammoudi DS, Simpson ER, Altomare F: Multimodal fundus imaging in choroidal osteoma. Am J Ophthalmol. 2012; 153: 890-895.e3.

17. Noble KG: Bilateral choroidal osteoma in three siblings. Am J Ophthalmol. 1990; 109: 656-660.

18. Katz RS, Gass JD: Multiple choroidal osteomas developing in association with recurrent orbital inflammatory pseudotumour. Arch Ophthalmol. 1983; 101: 1724-1727.

19. Trimble SN, Schatz H, Schneider GB: Spontaneous decalcification of a choroidal osteoma. Ophthalmology. 1988; 95: 631-634 .

20. McLeod BK: Choroidal osteoma presenting in pregnancy. Br J Ophthalmol. 1988; 72: 612-614.

21. Cunha SL: Osseous choristoma of the choroid: $A$ familial disease. Arch Ophthalmol. 1984; 102: 1052-1054. [PubMed: 6743084]

22. Aoki J: Familial bilateral occurrence of choroidal osteoma. Jpn J Ophthalmol. 1985; 39: 1319-1322.

23. Figueira EC, Conway RM, Francis IC: Choroidal osteoma in association with Stargardt's dystrophy. Br J Ophthalmol. 2007; 9: 978-979.

24. Fine HF, Ferrara DC, Ho IV, Takahashi B, Yannuzzi LA: Bilateral choroidal osteomas with polypoidal choroidal vasculopathy. Retinal Cases Brief Rep. 2008; 2: 15-17.

25. Spies AK, Teitelbaum BA, Aide FK: An atypical case of choroidal osteomas. Optometry. 2001; 72: 322-326.

26. Kline LB, Skalka HW, Davidson JD, Wilmes FJ: Bilateral choroidal osteomas associated with fatal systemic illness. Am J Ophthalmol. 1982; 93: 192-197.

27. Shields CL, Shields JA, Augsburger JJ: Choroidal osteoma. Surv Ophthalmol. 1988; 33: 17-27.
28. Bloom PA, Ferris JD, Laidlaw A, Goddard PR: Appearances of choroidal osteomas with diagnostic imaging. British Journal of Radiology. 1992; vol. 65, no. 778: pp. 845-848.

29. Nagasawa T, Mitamura Y, Katome T, Shinomiya K, Naito T, Nagasato D, et al.: Macular choroidal thickness and volume in healthy pediatric individuals measured by swept-source optical coherence tomography. Invest Ophthalmol Vis Sci. 2013; 54: 7068-7074.

30. Nagasawa T, Mitamura Y, Katome T, Nagasato D, Tabuchi H: Swept-source optical coherence tomographic findings in morning glory syndrome. Retina. 2014; 34: 206-208.

31. Lafaut BA, Mestdagh C, Kohno T, Gaudric A, de Laey JJ: Indocyanine green angiography in choroidal osteoma. Graefe's Archive for Clinical and Experimental Ophthalmology. 1997; vol. 235, no. 5: pp. 330-337.

32. Foster BS, Fernadez-Suntay JP, Dryja TP, Jakobiec FA, D'Amico DJ: Surgical removal and histopathologic findings of subfoveal neovascular membrane associated with choroidal osteoma. Arch Ophthalmol. 2003; 121: 273-276.

33. Mansour AM, Arevalo JF, Al Kahtani E, Zegarra H, Abboud E, Anand R, et al.: Role of Intravitreal Antivascular Endothelial Growth Factor Injections for Choroidal Neovascularization due to Choroidal Osteoma. Journal of Ophthalmology. J Ophthalmol. 2014; 2014: 210458. Epub 2014 Jul 23.

34. Jumaat BH, Dahalan A, Mohamad M: Bone in the eye. American Journal of Ophthalmology. 2003; vol. 135, no. 2: pp. 254$-256$.

35. Koylu MT, Gokce G, Durukan UYA.H: Secondary to Choroidal Osteoma Unassociated with Choroidal Neovascularization. Case Reports in Ophthalmological Medicine. Vol. 2014, Article ID 823953.

36. Aylward GW, Chang TS, Pautler SE, Gass JDM: A Long-term Follow-up of Choroidal Osteoma. Arch Ophthalmol. 1998; 116(10): 1337-1341.

37. Avila MP, El-Markabi $H$, Azzolini C, Jalkh AE, Burns D, Weiter JJ: Bilateral choroidal osteoma with subretinal neovascularisation. Ann Ophthalmol. 1984; 16: 381-385.

38. Morris RJ, Prabhu VV, Shah PK, Narendran V: Combination therapy of low-fluence photodynamic therapy and intravitreal ranibizumab for choroidal neovascular membrane in choroidal osteoma. Indian Journal of Ophthalmology. 2011; vol. 59, no. 5: pp. 394-396.

The paper was originally received 13.06.2018 (KO-00164-2018)/ Praca wpłynęła do Redakcji 13.06.2018 r. (KO-00164-2018) Accepted for publication 03.11.2018/ Zakwalifikowano do druku 03.11.2018 r.

Reprint requests to (Adres do korespondencji): Justyna Jędrychowska-Jamborska, MD Department of Ophthalmology and Ocular Oncology University Hospital, Kraków, Poland Mikołaja Kopernika 36 30-001 Kraków e-mail: justynajedrychowska@gmail.com 